Flourishing or Floundering? Policing the boundaries of Economic Geography

Mia Gray

Department of Geography,

Cambridge University,

CB2 3EN, UK

Jane Pollard

Centre for Urban and Regional Development Studies,

School of geography, Politics and Sociology,

Newcastle University, NE1 7RU, UK

Published in Environment and Planning A: Economy and Space

https://journals.sagepub.com/doi/pdf/10.1177/0308518X18810530

Please note: Changes made as a result of publishing processes such as copy-editing, formatting and page numbers may not be reflected in this version. For the definitive version of this publication, please refer to the published source. You are advised to consult the publisher's version if you wish to cite this paper. 


\section{Flourishing or Floundering? Policing the boundaries of Economic Geography}

The study of economic geography is thriving. After decades of arguing for the importance of understanding the spatialities of the economy, many economists have taken heed and tried to incorporate some geographic insights into their analyses. The once radical assertion that space, place and flows shape economies is increasingly recognized, understood and valued it seems by governments, think-tanks, and policy makers of all stripes (Barnes, 2018, Martin 2018). Across the university sector, the numbers of people interested in and undertaking research in economic geography appears to be growing; the 2018 Global Conference in Economic Geography in Köln had 772 participants from over 50 countries (up from just under 700 attendees at the same conference in Oxford 2015). Economic geography journals appear to be thriving, well read and cited (Rodriguez-Pose 2018). Undergraduate students flock to economic geography courses. Within the discipline, urban, cultural, environmental and development geographers have embraced the economic and strengthened our insights and interactions with other parts of geography. These researchers may not identify as Economic Geographers, but they produce economic geographical scholarship, cross-fertilise the subdiscipline, attend economic geography conferences and publish in economic journals.

Yet, paradoxically, here we are debating the decline of Economic Geography (James et al. 2018, Martin 2018), its marginalisation as a sub-discipline (Cumbers 2018) and the 'existential angst' that accompanies the idea that one of our big loves may be 'potentially deep sixing' (Barnes 2018:1). The sources of these concerns are summarised by James et al. (2018) who, in particular, highlight the exodus of UK economic geographers into business and management schools, 'hollowing out' the critical mass of the sub-discipline (James et al. 2018: 24) and arguably threatening its sustainability. 
Our response to this paradox is that it is too broad a critique to capture the multilayered change in economic geography and we need to clearly specify some of the different elements of this debate and say something more about both their temporality and - crucially for this discussion - their spatiality. For starters, the paradox outlined above begs the question of what is the unit of analysis in this debate? Is it a subdiscipline called Economic Geography and/or economic geographical scholarship (see Cockayne et al. 2018)? In what follows, we try and cut through some of the issues concerned by way of making some comments on the voice(s) and home(s) of Economic Geography and economic geographical scholarship.

\section{Voice(s)}

This debate about the production and reproduction of economic geography is, in large part, a debate about voice. Whose voices 'count', whose matter and whose get heard? Susan Christopherson (1989:84) has long since reminded us of the importance of questioning who is defining "the project", who is participating, whose theories have validity and significance. On this score, it is worth interrogating some elements of the debate that stand out, not least generation, gender and race and ethnicity.

First, there is a strong generational context to this debate about the past and future of economic geographical scholarship. A generation of economic geographers are at or nearing retirement age (see James et al. 2018), and these losses to the subdiscipline, economic geographical scholarship and disciplinary leadership more broadly, are not confined to the UK (for example, we can also think of Susan Hanson, David Harvey, Ann Markusen, Dick Peet, Allen Scott, Dick Walker, Michael Webber). We can also include the losses of Neil Smith, Ed Soja, Doreen Massey, and Susan Christopherson. Some of the disquiet and sense of change 
in economic geography comes from this transition - in voice and in active leadership - away from this generation who were profoundly influential in shaping the sub-discipline since the 1970s.

If generational change shapes part of the unease discussed by James et al. (2018), then so too do gender, race and ethnicity in what is (still) one of the most masculinized and white parts of Human Geography. Whether economic geography's 'male, pale and stale' (Cumbers 2018:7) reputation is narrated as a curse or just-something-that-it-is-hard-to-do-much-about depends on your location and sensitivity to difference. Running through James et al. (2018), however, is a nostalgia for the golden days of 1980s/1990s radical political economy (and the gendered, raced and generational voices that went with it). Some foundational and inspirational work was produced in that period and we were both socialised in that period. Yet one of the great (and saddest) ironies of economic geography has been its reluctance to tackle its own political economy:

"There is a palpable frustration with the dominant epistemologies and analytical, empirical, and political exclusions that persist within mainstream and radical economic geography. We are wary of not only the silences in who speaks and what gets spoken, but also the gaps in our empirical explanations. To speak in the abstract about capitalism - to separate analyses of its practices, laws, and articulations from social formations - presumes the non-centrality of gender and race to the operation of capitalism, and relegates approaches engaging with social difference as separate from, or less than fundamental to, traditional political economy. Yet it also prevents us from adequately understanding how capitalism is reproduced and differentiated over time and space (Werner et al. 2017: 3-4). 
This argument is directly related to whether we think economic geography is floundering or flourishing. Economic geography would appear to be flourishing in terms of the kinds of messages it is sending, and in attracting a plural, increasingly diverse group of people interested in economic geographical work. We should recognise and celebrate this economic geographical scholarship, even when it is not part of 'Economic Geography' as a sub-discipline. We argue we should be less concerned with policing the boundaries of economic geography and embrace the economic geographic scholarship in development geography, urban geography, environmental geography and, indeed, in business schools. As Gibson-Graham (1996) reminds us, the economic is diverse, and this should be reflected in our theories and approaches. The "loss" of economic geographers to other sub-disciplines and to business schools may actually be seeding the next generation of economic geographical thought.

\section{Home(s)}

A second, not unrelated, element of the paradox surrounding contemporary economic geography is the multiple senses of 'home' (and/or 'location') being invoked in these debates. One sense of this, already alluded to, is the nostalgia for a particular kind of geographical political economy of the 1980 s and 1990s. Another sense of home that is critical to this debate, and we suspect underspecified thus far, is the UK-centred nature of the debate. The UK has long been a home of 'historically outsized influence' for economic geography (Cockayne et al. 2018). Having said that, as Rodriguez-Pose (2018) argues, Dutch, Scandinavian and German scholars are now much more visible in scholarship and disciplinary engagement. Perhaps this "crisis" reflects challenges to the UK-centric nature of economic geography and that is no bad thing. 
There are peculiar elements of the UK context, however, that bear considering in this debate. First, it is worth noting, most especially for international readers, that the UK University remuneration system is characterised by a centrally negotiated national pay scale. In a neoliberalizing context, UK universities have witnessed a proliferation in senior management roles and ballooning pay for Vice Chancellors, whilst most rank and file academics have endured a systematic erosion in their real wages and terms and conditions of employment. The recent (and ongoing) industrial dispute in the UK centred on pension provision, but academics' unprecedented willingness to strike for 14 days in early 2018 evidences a wider erosion of faith in employment conditions in UK universities and, again, this is generational. In this context, Business and Management Schools stand out in two regards. First, along with other professionally oriented schools, they offer a route to salaries less constrained by national pay agreements. Second, UK business and management schools are enjoying something of a bubble; they are awash with international students paying international fees and, as such, have become essential cash-cows (and sites of investment) for UK universities. The flip side of the 'is economic geography declining' question is thus the booming political economy of business school education in the UK, which is affecting disciplines beyond geography (Cumbers 2018).

A second point to note here about the UK political economy of this debate is that economic geographers at all career stages have long been willing to leave UK economic geography for better opportunities elsewhere: Trevor Barnes, Jamie Peck, Eric Sheppard, Allen Scott and Michael Webber to name only a few key figures in the discipline, moved to North America and beyond to work in better resourced environments for remuneration, research funding, graduate students, libraries and all the other trimmings of university life. Economic geographers are still moving to the better conditions offered elsewhere, this time 
within the UK to business and management schools; the effects of this on the nature of their work and disciplinary identity appear to be mixed (James et al. 2018, Cumbers 2018). So there is a particular political economy to this perfect storm facing Economic Geography in the UK, one that might lead us to worry less about 'what's wrong with Economic Geography' and, more generally, to contemplate the likely repercussions for UK universities when the business school bubble bursts, be that when international students opt to do their degrees elsewhere or because of calls for the development of more critical, reflexive business and management education (Parker 2018).

The other element of 'home' to be discussed is in terms of the reproduction of scholars undertaking economic geographical scholarship. Where is Economic Geography, both as a form of scholarship and as a subdiscipline? The 'it's floundering' camp sees its home in a Geography discipline and institutionally in a Geography department. On that score, Economic Geography is in trouble and James et al. (2018) cite the declining significance of economic geography in geography departments in Bristol, Birmingham, Cambridge, Glasgow, Manchester and the Open University (and note Newcastle, Cardiff, Queen Mary University London, LSE and Nottingham as centres of consolidation). But many early career economic geography scholars place themselves elsewhere - either institutionally, as discussed above, or within the discipline - some place themselves in "cultural economy", others in "sustainability". These scholars actively engage in the field, write in the same journals, attend the same conferences, and engage in the same debates. We argue that a strict policing of the boundaries of where economic geography starts and stops is counterproductive and creates its own sense of crisis by ignoring the corpus of exciting economic geographical research being produced by a wide range of scholars. 
This is not to say that there are not disciplinary and spatial issues to discuss. The extent to which Economic Geography can reproduce itself in the nooks and crannies offered in sociology, development, political science, planning and business schools is an open question. More generally, what is the future of the sub-discipline and how does it reproduce itself in universities which embrace post-disciplinary liberal arts/social science research (see Cockayne et al. 2018)? These are important questions, but are not quite what James et al. (2018) highlight.

\section{Solutions?}

We argue that the institutional and disciplinary diffusion of economic geography is both a danger and an opportunity. James et al. (2018) suggest ways to define and reinforce the 'core' of economic geography - both intellectually and at an institutional level by creating critical mass for those economic geography researchers in different departments, but defining and reinforcing the 'core' risks disqualifying or marginalising those working outside the "core." It suggests that some research agendas are more valid than others and brings us back to decades-old debates over the definition of 'the economic' and who is allowed to define it (Gibson-Graham, 1996).

James et al.'s (2018) other solution strikes us as more promising. That is to create a larger sense of what economic geography can be by connecting some disciplinary hotspots. The large centres of the sub-discipline are able through their critical mass to shape agendas on cities, on inequality, on finance, on austerity (see Leyshon 2018). When done well, this approach will not try to police the boundaries of economic geography, but will invite and embrace plurality and diversity. In short, rather than defining a narrow 'core', we call for economic geography to lower the fences, be more inclusive, and to welcome the presence of 
more diverse voices. We call not for the reconstruction of Economic Geography, but rather the embrace of economic geography.

\section{References}

Barnes, T (2018) Decline and Fall? Environment and Planning A, https://doi.org/10.1177/0308518X18781087

Christopherson S (1989) On being outside 'the project', Antipode 21: 83-89.

Cockayne D, Horton A, Kelly K, Loomis J and Rosenman E (2018) On economic geography's "movers" to business and management schools: A response from outside "the project", Environment and Planning $A$ https://doi.org/10.1177/0308518X18796506

Cumbers A (2018) What is a 'person' like you doing in a 'place' like that? Reflections on the business school migration from economic geography, Environment and Planning $A$ http://journals.sagepub.com/doi/full/10.1177/0308518X18782704

James, A., Bradshaw, M., Coe, N.M. and Faulconbridge, J. (2018) Sustaining Economic Geography? Business/Management Schools and the UK's Great Economic Geography Diaspora. Environment and Planning A, https://doi.org/10.1177/0308518X18764120

Leyshon A (2018) Unfinished business, Environment and Planning A https://doi.org/10.1177/0308518X18784599

Parker, M. (2018) Shut Down the Business School. What's Wrong with Management Education. London: Pluto Press.

Rodriguez-Pose, A (2018) Threat or opportunity? On the 'cross- corridor diaspora' of British economic geographers, Environment and Planning $A$ https://doi.org/10.1177/0308518X18796509

Werner, M, Strauss K, Parker B, Orzeck, R, Derickson, K and Bonds a (2017) Feminist political economy in geography: Why now, what is different, and what for? Geoforum 79: 1-4 
